\title{
THE ORTHOPTERA (INSECTA) FROM MIDDLE AND LOWER PRUT RIVER BASIN
}

\author{
IONUŢ ŞTEFAN IORGU, NADEJDA STAHI, ELENA IULIA IORGU
}

\begin{abstract}
The ecological preferences and bioacoustics of bush-crickets, crickets and grasshoppers species were studied in middle and lower Prut River basin, a research conducted in 55 localities from Romania and 33 localities in the Republic of Moldova. A total number of 91 species of Orthoptera were collected in the study area: 85 species encountered on the western side of Prut River basin $(9$ Phaneropteridae, 24 Tettigoniidae, 1 Bradyporidae, 5 Gryllidae, 1 Gryllotalpidae, 1 Tridactylidae, 5 Tetrigidae, 39 Acrididae) and 76 species found on the eastern side (7 Phaneropteridae, 19 Tettigoniidae, 1 Bradyporidae, 5 Gryllidae, 1 Gryllotalpidae, 1 Tridactylidae, 3 Tetrigidae, 39 Acrididae). Four species are recorded for the first time in the Orthoptera fauna of the Republic of Moldova: Barbitistes constrictus (Fabricius), Poecilimon fussii Brunner von Wattenwyl, Metrioptera roeselii fedtschenkoi (Saussure) and Pholidoptera frivaldskyi (Herman).
\end{abstract}

Résumé. Les préférences écologiques et bioacoustique des espèces de sauterelles, grillons et criquets ont été étudiés dans le bassin moyen et inférieur du fleuve Prut, une recherche menée dans 55 localités de la Roumanie et de 33 localités dans la République de Moldova. Un total de 91 espèces d'orthoptères a été recueillis dans la zone d'étude: 85 espèces rencontrées sur le côté d'ouest du bassin de la rivière Prut (9 Phaneropteridae, 24 Tettigoniidae, 1 Bradyporidae, 5 Gryllidae, 1 Gryllotalpidae, 1 Tridactylidae, 5 Tetrigidae, 39 Acrididae) et 76 espèces présentes sur la côte orientale (7 Phaneropteridae, 19 Tettigoniidae, 1 Bradyporidae, 5 Gryllidae, 1 Gryllotalpidae, 1 Tridactylidae, 3 Tetrigidae, 39 Acrididae). Quatre espèces sont enregistrées pour la première fois dans la faune d'Orthoptères de la République de Moldova: Barbitistes constrictus (Fabricius), Poecilimon fussii Brunner von Wattenwyl, Metrioptera roeselii fedtschenkoi (Saussure) et Pholidoptera frivaldskyi (Herman).

Key words: Orthoptera, biodiversity, acoustics, distribution, Prut.

\section{INTRODUCTION}

The middle and lower Prut River forms the natural border between Romania and the Republic of Moldova. Prut floodplain covers a vast range of natural habitats with a stunning diversity of flora and fauna (Radu et al., 2012); from marsh habitats and riparian forests to steppic mesophytic and xerophytic meadows, this area provides perfect biotopes for a large number of bush-crickets, crickets and grasshoppers. In fact, the highest known density of Orthoptera species in Romania occurs in a small area from the Prut Basin: Valea lui David (David's Valley) Natural Reserve, near Iaşi. This old steppic grassland is the intersection of Palearctic, European, Eurosiberian, Central-Asian European, Mediterranean and Pontic elements, being a true example of natural steppic vegetation, nowadays almost disappeared from Romania and Europe. Located at about $47^{\circ} 11^{\prime} 35^{\prime \prime} \mathrm{N}$ and $27^{\circ} 28^{\prime} 08^{\prime \prime} \mathrm{E}$ and overlapping with ROSCI0265, Valea lui David is classified as IUCN IV-th class and represents the most important site for biodiversity conservation along Prut Basin in Romania (Popescu, 2013).

The Orthoptera species in Prut Basin were studied by Mîndru (1958 a, b, 1960, 1980), Mîndru \& Kis (1967), Bizuţchi (2004), Derjanschi et al. (2006), Stahi (2006, 2007 a, b, 2009), Stahi \& Derjanschi (2007, 2008, 2010, 2011 a, b, 2012), I. Ş. Iorgu \& E. I. Iorgu (Pisică) (Iorgu \& Pisică, 2006; Iorgu \& Iorgu, 2008; Iorgu 
\& Pisică, 2008; Iorgu et al., 2008), Pricop et al. (2012). Recently, a new subspecies of bush-cricket has been described from the surroundings of Suceava and Dorohoi (Iorgu \& Heller, 2013). Besides taxonomic and ethological investigations, the Orthoptera communities have been recently studied also as food source for Vipera ursinii moldavica Nilson, Andrén et Joger, with particular emphasis on the presence of Saga pedo Pallas, as a perfect indicator of the steppic habitat status (Zamfirescu et al., 2007; Zamfirescu et al., 2009).

Four Orthoptera species from the border area Romania - Republic of Moldova have been recently proposed for the flora and fauna red list: Saga pedo (IUCN - VU), Onconotus servillei Fischer de Waldheim (IUCN - VU), Callimenus macrogaster Lefebvre (IUCN - EN) and Bradyporus dasypus Illiger (Oprea et al., 2008 a, b; IUCN, 2013).

The aims of this paper are to gather new data on the Orthoptera fauna from the middle and lower Prut River basin, by providing an updated list of Orthoptera species, and to identify and study the Orthoptera assemblages from this area. For this purpose, we will analyze the species distribution in the sampling sites.

\section{MATERIAL AND METHODS}

Data collection. The sampling was made by sweeping herbal vegetation with the entomological net and the shrubs and trees with an entomological umbrella; we also used acoustic identification of singing males. Investigated sampling sites were classified in seven habitat categories: hygrophytic meadows (HM), halophytic meadows (hM), steppic mesophytic meadows (MM), steppic xerophytic meadows $(\mathrm{XM})$, ruderalized $(\mathrm{R})$, pastures $(\mathrm{P})$, forest clearings $(\mathrm{F})$.

Sampling sites. The Orthoptera were collected from 55 localities (133 sites) in Romania and 33 localities (61 sites) in Republic of Moldova (Fig. 1).

Romania: Hilişeu-Crişan, Botoşani county (MM, F); Hilişeu-Horia, Botoşani county (R, XM); Şendriceni, Botoşani county (MM, R, F); Gorovei, Botoşani county (F); Baisa, Botoşani county (F); Botoşani, Botoşani county (R); Vorona, Botoşani county (R, F); Oneaga, Botoşani county (R, F); Vlădeni-Deal, Botoşani county (F); Cotu, Botoşani county (F); Coşula, Botoşani county (MM, R, P, F); Vânători, Botoşani county (F); Drislea, Botoşani county (MM, F); Loturi, Botoşani county (R, F); Zahoreni, Botoşani county (F); Bârsăneşti, Botoşani county (HM, MM, F); Cucuteni, Botoşani county (P); Ştefăneşti, Botoşani county (R, P); Bobuleşti, Botoşani county (P); Bogdăneşti, Botoşani county (P, F); Berza, Botoşani county (MM, XM, F); Humosu, Iaşi county (F); Vlădeni, Iaşi county (HM, R, P); Larga Jijia, Iaşi county (HM, R, P); Trifeşti, Iaşi county $(\mathrm{P}, \mathrm{F})$; Probota - Bălătău Prut, Iaşi county (HM, R, F); Cotu Morii, Iaşi county (P, F); Lețcani - Valea Ilenii, Iaşi county (HM, hM, MM, R); Cogeasca, Iaşi county (R, P); Valea lui David, Iaşi county (HM, hM, MM, XM, R); Horleşti, Iaşi county (HM, MM, XM, R); Mârzeşti - Breazu, Iaşi county (HM, hM, MM, XM, R, F); Aroneanu, Iaşi county (HM, R, F); Iaşi, Iaşi county (HM, MM, R, F); Dancu, Iaşi county (HM, R, P); Păun, Iaşi county (R, F); Bârnova, Iaşi county (MM, R, F); Picioru Lupului, Iaşi county (MM, R); Curături, Iaşi county (HM, MM, R, P, F); Slobozia, Iaşi county (R, F); Tomeşti, Iaşi county (HM, R), Costuleni, Iaşi county (HM, MM, R); Răducăneni, Iaşi county (MM, R), Drânceni, Vaslui county (MM, R); Epureni, Vaslui county (R, F); Huşi, Vaslui county (MM, R, F); Lunca Veche, Vaslui county (R, MM); Fălciu, Vaslui county (MM, P, R); Rânzeşti, Vaslui county (P, R); Murgeni, Vaslui county (P, R); Cavadineşti, Galaţi county (XM, P, R); Oancea, Galaţi county (XM, P, R); Roşcani, 


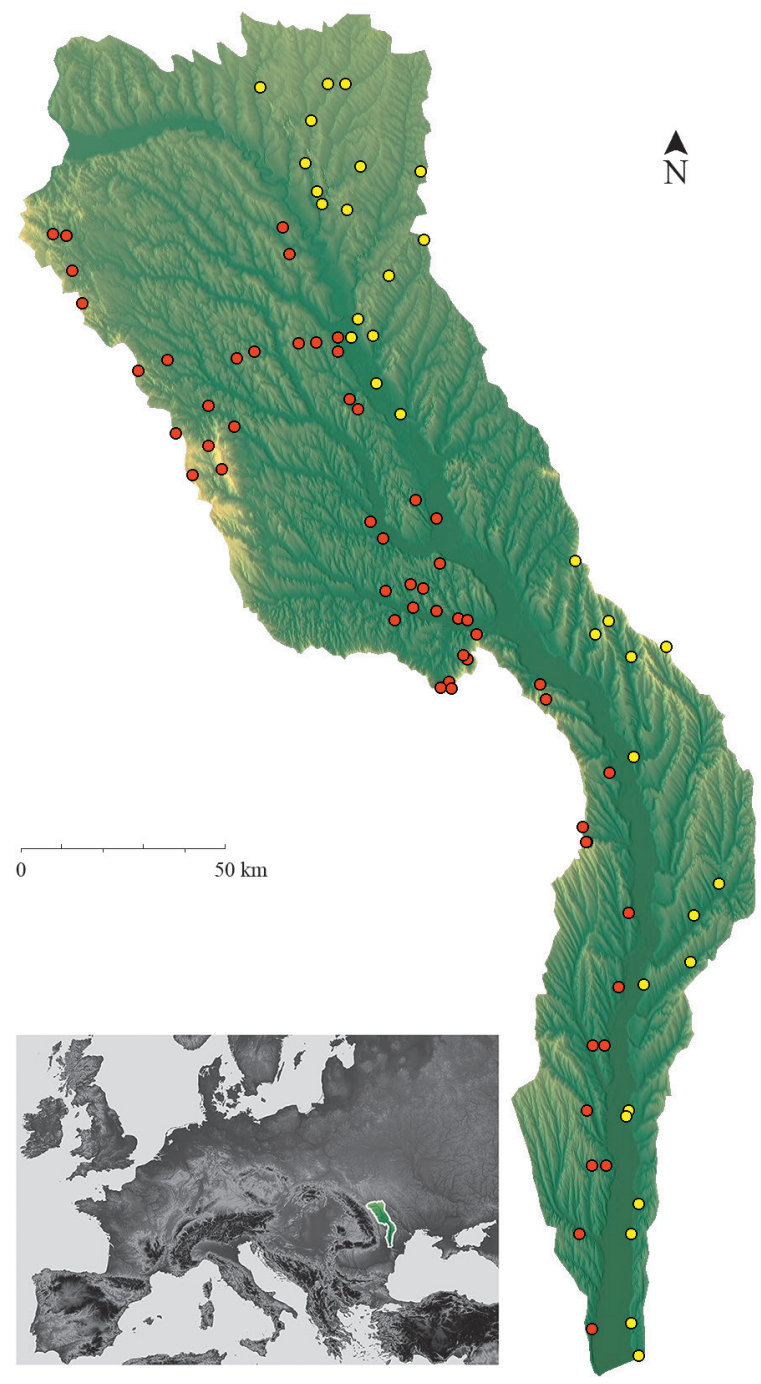

Fig. 1 - Map of middle and lower Prut Basin: red dots, collecting areas in Romania; yellow dots, collecting sites in Republic of Moldova.

Galaţi county (P, R); Chiraftei, Galaţi county (P, R, F); Tuluceşti, Galaţi county (HM, R).

Republic of Moldova: Trebisăuţi, Briceni district (HM); Cotiujeni, Briceni district (HM, P); Trestieni, Briceni district (P); Corestăuţi, Ocniţa district (HM); Edineț, Edineț district (HM); Buzdujeni, Edineț district (XM); Brînzeni, Edineț district (HM, XM); Gaşpar, Edineț district (HM); Feteşti, Edineţ district (XM); Zăbriceni, Edineţ district (XM); Hiliuţi, Râşcani district (HM); Vasileuţi, Râşcani district (R, P); Păscăuţi, Râş̧cani district (HM, R); Branişte, Râşcani district (HM, XM); Moara Domnească, Glodeni district (HM, MM, XM, F); Buteşti, Glodeni district (HM, MM); Balatina, Glodeni district (HM, MM, P); Rădenii-Vechi, Ungheni district (HM, MM, F); "Codrii” Natural Reserve, Străşeni district (HM, 
MM, XM, F); Păruceni, Nisporeni district (FM, R); Nisporeni, Nisporeni district (XM, P, F); Boldureşti, Nisporeni district (R); Sărățeni, Hânceşti district (hM); Tigheci, Leova district (MM, XM); Sărata Nouă, Leova district (hM, R); Troiţa, Leova district (XM); Antoneşti, Cantemir district (XM); Crihana Veche, Cahul district (R); Cucoara, Cahul district (R); Giurgiulești, Cahul district (XM, AX, P); Paicu, Cahul district (R, P); Slobozia-Mare, Cahul district (HM, XM, AX, P); Vadul-lui-Isac, Cahul district (XM, P).

Song recording and analysis. Audio recordings were taken with Edirol R-09HR digital recorder, having the microphone frequency response of 20-40.000 $\mathrm{Hz}$, sampling rate of $96.000 \mathrm{~Hz}$ and 24-bit amplitude resolution. Sound analysis was performed with the software Audacity 2.0.5. Song terminology and abbreviations are adapted from Ragge \& Reynolds (1998) and Heller et al. (2004).

Data analysis. We used Kruskal-Wallis test to differentiate between the Orthoptera assemblages from the seven habitat categories in the two countries, by comparing the number of species among the habitats. In addition, in order to classify the habitat types into correlated groups based on the Orthoptera species composition, we employed the cluster analysis with Jaccard similarity index. All statistical analyses and evaluations were performed with Past 3.01 (Hammer et al., 2001).

\section{RESULTS AND DISCUSSION}

91 Orthoptera species were found in the Prut River basin area, represented by 43 Ensifera (19 Tettigoniidae, 10 Phaneropteridae, 6 Gryllidae, 4 Conocephalidae, 1 Meconematidae, Sagidae, Bradyporidae and Gryllotalpidae) and 48 Caelifera (42 Acrididae, 5 Tetrigidae and 1 Tridactylidae) (Tab. 1).

The most frequently encountered species were the euribionts Tetrix tenuicornis, Ruspolia nitidula, Metrioptera roeselii and Chorthippus parallelus (present in all seven habitats), followed by Conocephalus fuscus, Tettigonia viridissima, Decticus verrucivorus, Metrioptera bicolor, Gryllus campestris, Pezotettix giornae, Stenobothrus lineatus, Chorthippus brunneus, Chorthippus biguttulus and Chorthippus oschei (present in six habitats), Leptophyes albovittata, Tettigonia caudata, Melanogryllus desertus, Modicogryllus frontalis, Oecanthus pellucens, Gryllotalpa gryllotalpa, Calliptamus italicus, Stenobothrus stigmaticus, Omocestus rufipes and Euchorthippus declivus (present in five habitats). A large number of stenobiont species were observed in the study area: Conocephalus dorsalis, Pteronemobius heydenii, Gryllomorpha dalmatina, Xya variegata, Tetrix ceperoi, Tetrix bolivari, Mecostethus parapleurus and Stethophyma grossum in hygrophytic meadows, Sphingonotus caerulans in halophytic meadows, Poecilimon brunneri, Conocephalus hastatus, Gampsocleis glabra, Decticus albifrons, Platycleis intermedia, Onconotus servillei, Oedaleus decorus, Dociostaurus maroccanus, Omocestus minutus and Chorthippus dichrous in xerophytic meadows.

The species composition in the Orthoptera assemblages found in Republic of Moldova differs significantly from the ones found in Romania in two out of the seven habitat categories: xerophytic meadows and ruderalized areas (Kruskal-Wallis test $p=0.02961$ and $p=0.02961$, respectively), however after the Bonferroni correction all the $\mathrm{p}$ values increased over the 0.05 threshold. Explanation for these results can be the different pesticide campaigns used in both countries. The Orthoptera assemblages in ruderalized habitats from Romania are not significantly different 


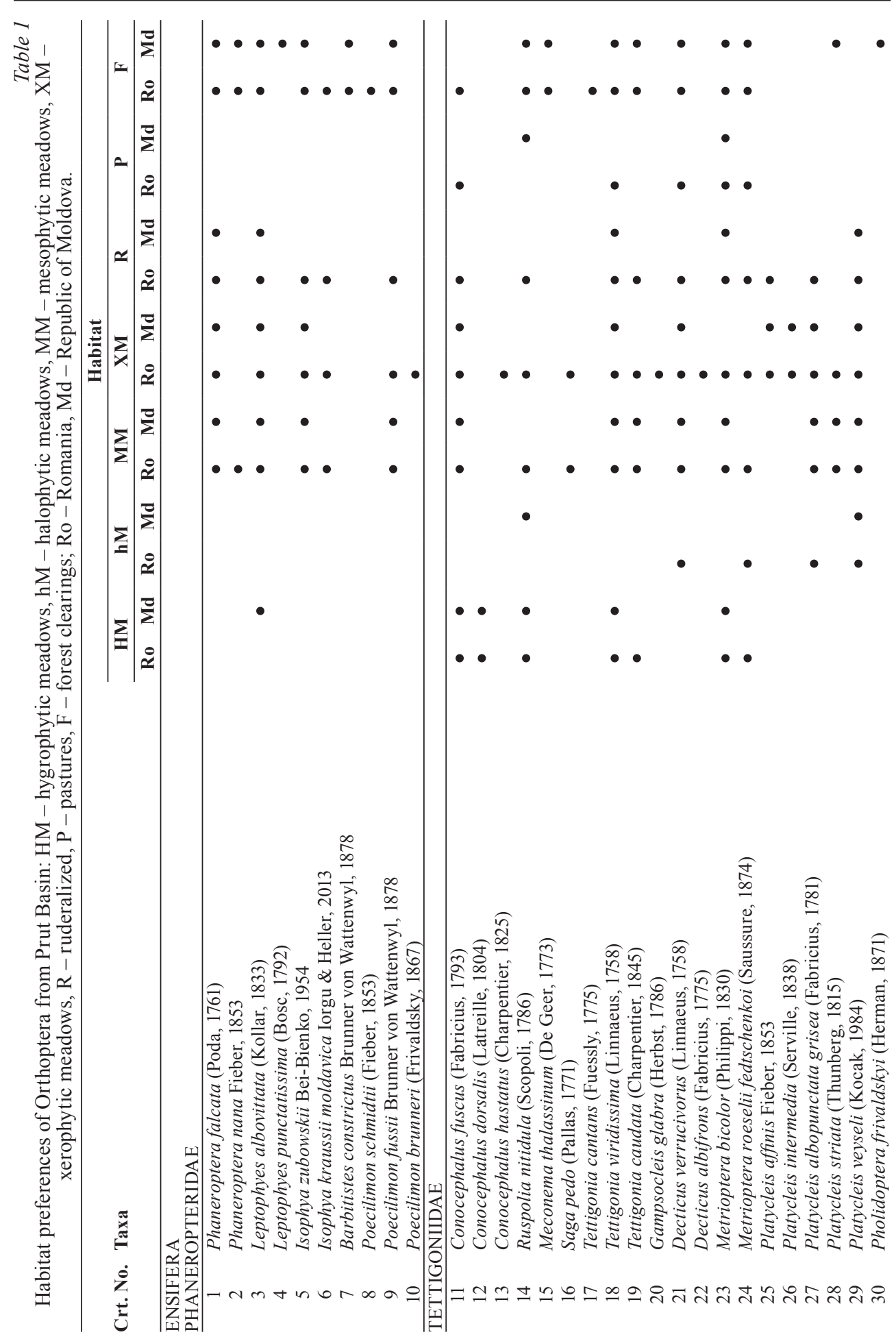




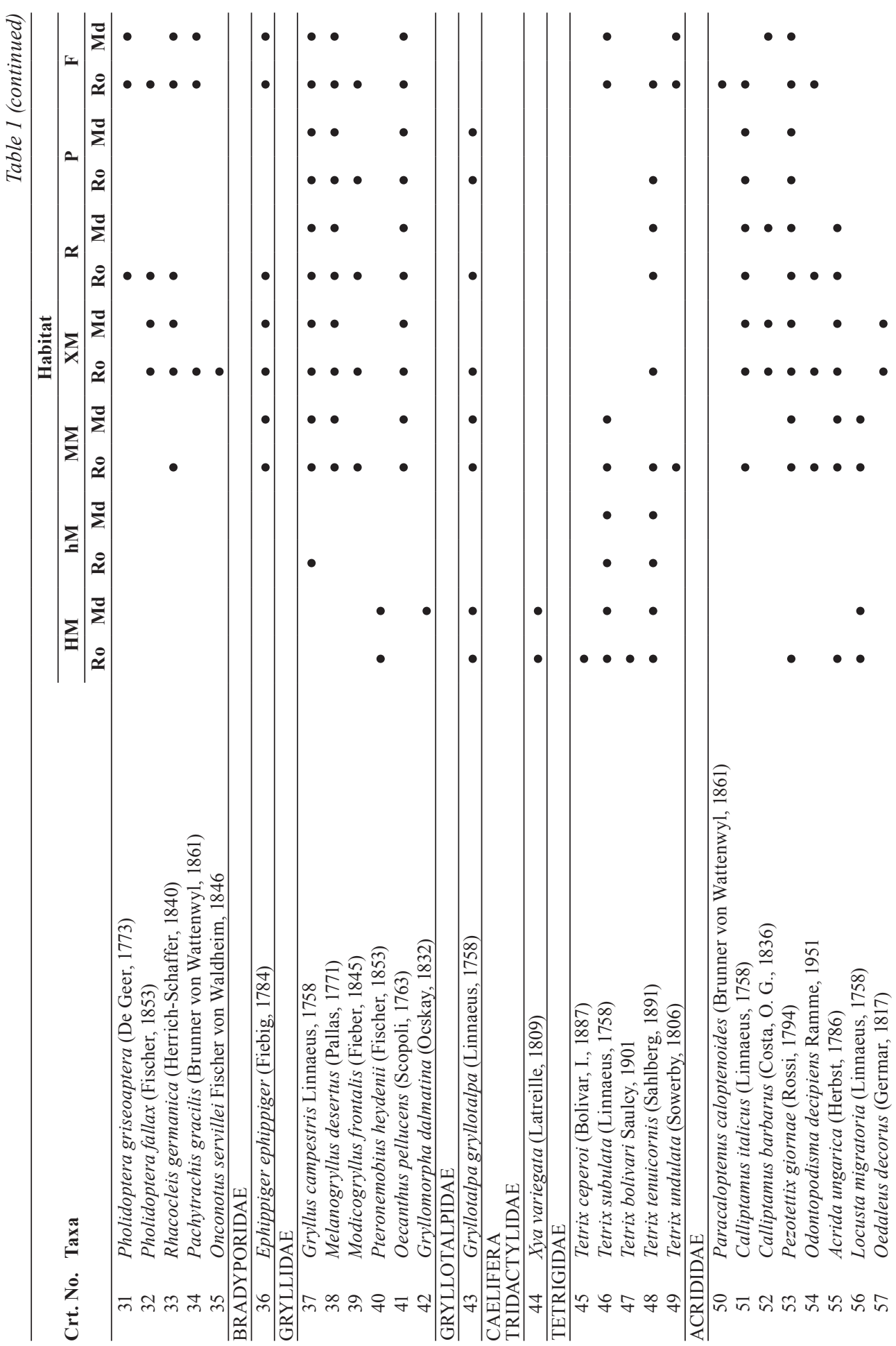




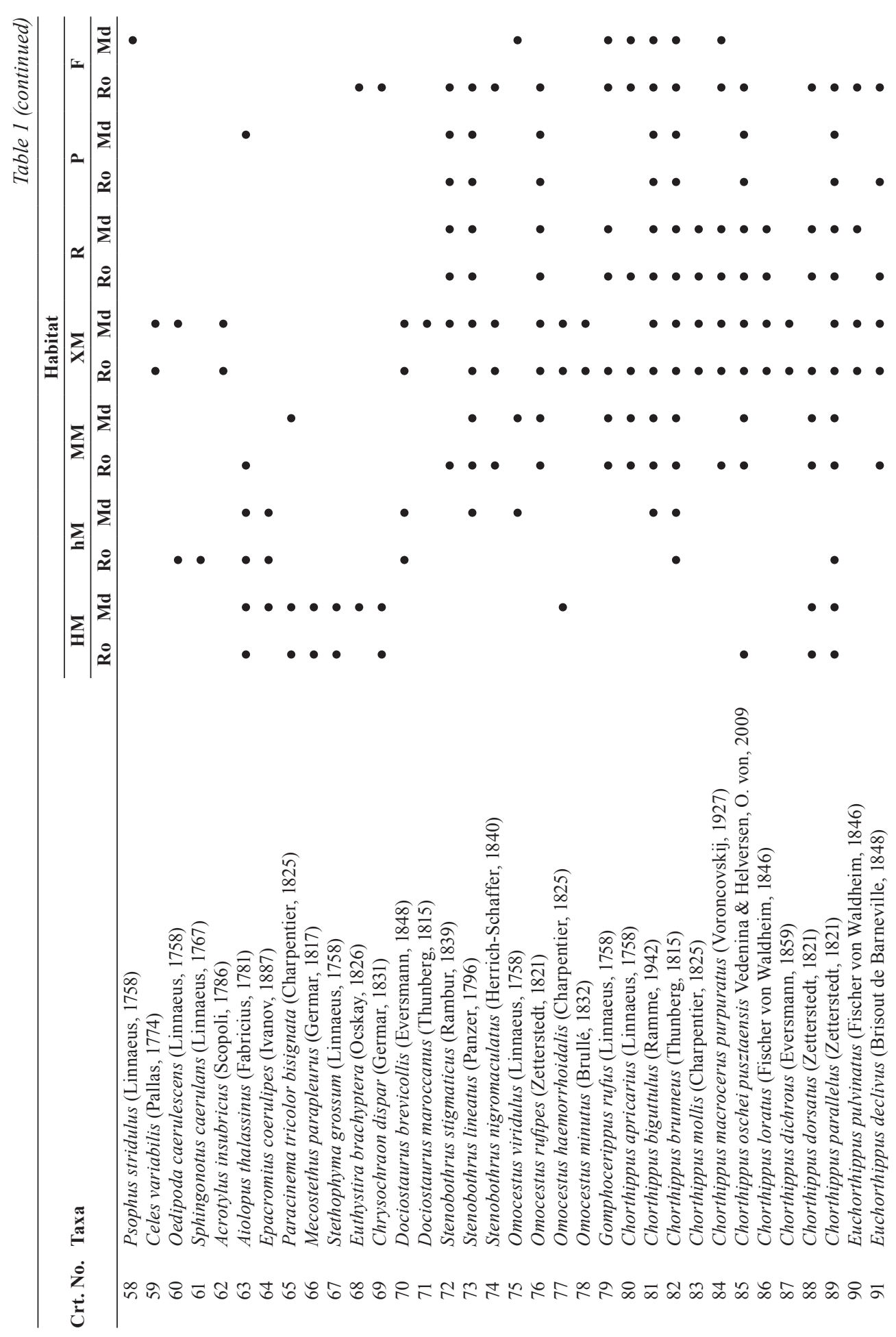


from any other analyzed habitat except halophytic meadows and the ones from Moldova are significantly different from xerophytic meadows.

A Jaccard similarity index cluster analysis of the habitat types based on the species presence/absence showed that halophytic meadows habitats from both countries grouped together. This can be explained by the presence in these habitats of xerophytic and geobiont species, such as Oedipoda caerulescens, Epacromius coerulipes, Dociostaurus brevicollis etc. (Fig. 2). In addition, the hygrophytic meadows habitats from both countries also grouped together, due to the presence of hygrophilous species, such as Conocephalus dorsalis, Pteronemobius heydenii, Gryllomorpha dalmatina and Xya variegata, found only in these habitats.

Another important grouping is the ruderalized habitats in the Republic of Moldova and the pasture habitat types from both countries. In addition, the xerophytic meadows (Romania and Moldova) grouped together with the mesophytic meadows (Romania and Moldova), the ruderalized habitats and the forest clearings (Romania). This is due to the presence of praticolous mesophytic and meso-xerophytic species, such as Metrioptera bicolor, Chorthippus biguttulus, Omocestus rufipes etc.

\section{Remarks on species.}

Barbitistes constrictus (Fabricius). Material: 1 o and 1 q, forest near

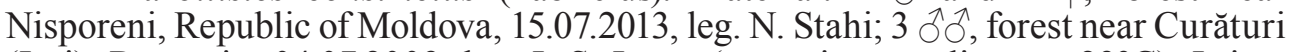
(Iaşi), Romania, 04.07.2009, leg. I. Ş. Iorgu (acoustic recordings at $23^{\circ} \mathrm{C}$ ). It is a fruticolous species; adults present during VI-VIII. The species' range covers Central and Eastern Europe, from Germany to Volga River, southwards extending into the high mountains of the Balkan Peninsula (Chobanov, 2009). The song consists of groups of 8-16 syllables, each followed shortly by an isolated syllable (Fig. 3 a, b). This is the first record of the species in the Republic of Moldova.

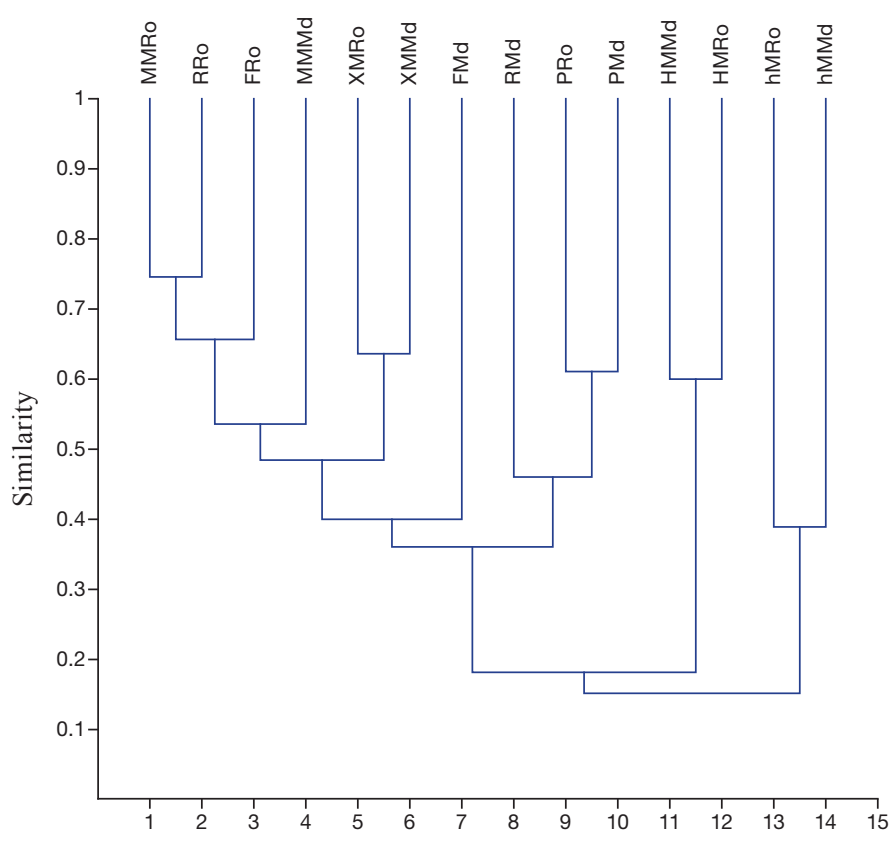

Fig. 2 - Habitat type cluster analysis (Jaccard index). 
a

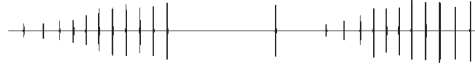

madidinatas

e
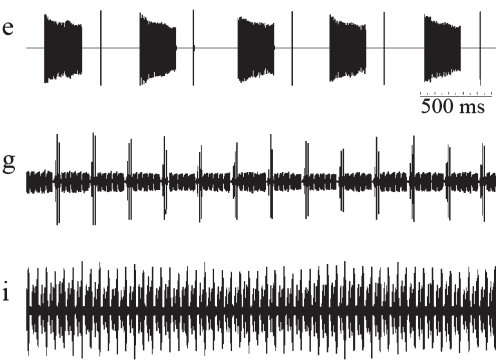

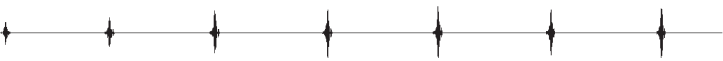

$\mathrm{d}$

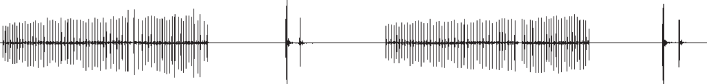

$\mathrm{f}$

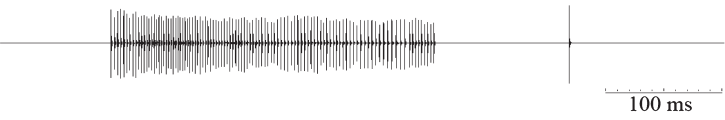

$\mathrm{h}$
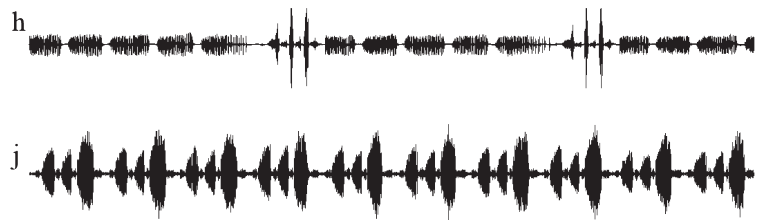

Fig. 3 - Oscillographic representation of calling song: a, b, Barbitistes constrictus (Curături, $23^{\circ} \mathrm{C}$ ); c, d, Isophya kraussii moldavica (Hilișeu-Crişan, $19^{\circ} \mathrm{C}$ ); e, f, Isophya zubowskii (Bârnova, $22^{\circ} \mathrm{C}$ ); g, h, Platycleis striata (Hilişeu-Horia, $\left.20^{\circ} \mathrm{C}\right) ; \mathrm{i}, \mathrm{j}$, Onconotus servillei (Valea lui David, $26^{\circ} \mathrm{C}$ ) (b, d, f, $\mathrm{h}, \mathrm{j}$ - detailed oscillograms).

Isophya kraussii moldavica Iorgu \& Heller (Figs 3 c, d; 4 a). This subspecies was recently described from NE Romania and differs from the nominal form (Central Europe) mainly in acoustics and less in morphology. Males from the Moldavian populations sing shorter syllables, formed of 30-58 impulses and lasting for about 89-200 ms, while males of the nominal subspecies produce longer syllables, formed of 80-125 impulses and lasting for about 250-443 ms. The stridulatory file is shorter (195-229 pegs) in I. kraussii moldavica, compared with 260-305 pegs in I. kraussii kraussii (Iorgu \& Heller, 2013). Adults are found during V-VI. Although found so far only on the western part of Middle Prut Basin, it is probable that this species populates also the NW part of Republic of Moldova.

Isophya zubowskii Bey-Bienkoi. Praticolous species, very common in the studied area. Adults occur in the same period as the previous species. The species sings at dusk and during the night, the calling song consisting of a temporal variable series of syllables, each formed of 74-118 impulses and lasting for 182-319 ms (Fig. 3 e, f).

Leptophyes punctatissima (Bosc). Kis \& Vasiliu (1970) mentioned the species from the surroundings of Hilișeu-Crişan, but it was not encountered during our studies in the area. It is very rare in the Republic of Moldova and recently found at "Codrii" Natural Reserve (02.08.2006, leg. N. Stahi). Adults can be found during VII-IX.

Poecilimon fussii Brunner von Wattenwyl. Common in the meadows of central and southern parts of the studied area. Adults can be found during VI-VIII. Material: $12 \widehat{\partial} \hat{\partial}$ and 29 우, Vadul lui Isac, 18.07.2011, leg. N. Stahi. This is the first record of the species in the Republic of Moldova.

Saga pedo (Pallas). Saga genus contains 13 species of the largest European bush-crickets. Saga pedo (Fig. 4 d) is the only parthenogenetic species within the genus and occupies a territory much larger than that of any other bisexual congeneric species, from the coast of Portugal to China and North America. The species is protected throughout its distribution area and it was evaluated as vulnerable in the 


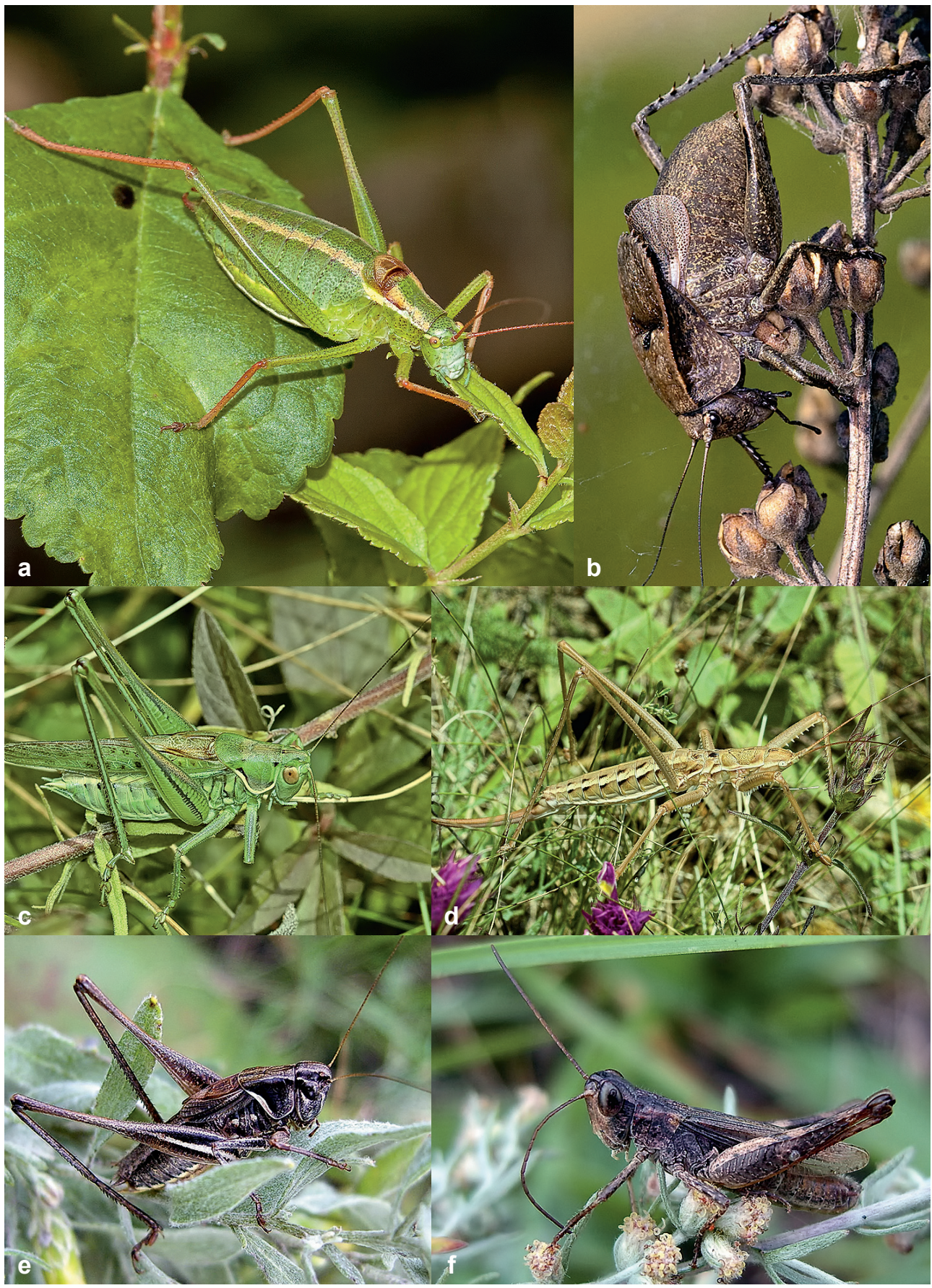

Fig. 4 - Habitus photos of some Orthoptera species from the studied area: a, Isophya kraussii moldavica ô (Hilişeu-Crişan); b, Onconotus servillei đo (Valea lui David); c, Gampsocleis glabra

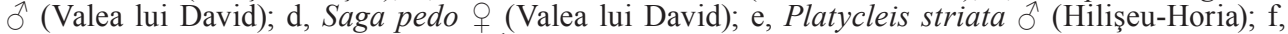
Chorthippus macrocerus purpuratus ờ (Iaşi). 
IUCN Red List of Threatened Species (Kolics et al., 2012; IUCN, 2013). Adults are found during VI-IX.

Tettigonia cantans (Fuessly). Adults are found during VI-X. Although known as a typical mountain species, this bush-cricket also occurs in lowland areas, such as the forests surrounding Iaşi (Romania).

Decticus albifrons (Fabricius). It is a thermo-xerophytic species, praticolous, usually living in high grasslands and shrubs. Adults are found during VI-IX. Being more common in Dobrogea (SE Romania), its presence at Valea lui David is unexpected, as it was discovered here recently (Iorgu \& Pisică, 2006).

Gampsocleis glabra (Herbst) (Fig. 4 c). It is a praticolous, xerophytic species, very rare in the studied areas; however, it looks like the population from Valea lui David (near Iaşi) is the strongest known in Romania (I. Ş. Iorgu, unpublished).

Metrioptera roeselii fedtschenkoi (Saussure). Material: $3 \delta^{\lambda} \sigma^{\lambda}$ and 1 \& „Codrii” Natural Reserve, 23.07.2012, leg. N. Stahi. Adults are found during VI-VIII. This is the first record of the species in the Republic of Moldova. In NE Romania, it is a common species in hygrophytic meadows.

Platycleis striata (Thunberg). Adults VI-IX (Fig. 4 e). A typical steppic, xerophytic species, localized in the studied area at Valea lui David - Mârzeşti Horleşti (Iaşi county), Drislea and Hilişeu-Horia (Botoşani county). Bioacoustics: the calling song consists of a long series of echemes, each echeme formed of a group of 4-6 macrosyllables (containing 44-68 impulses and lasting for 28-40 ms), always followed by 2-4 microsyllables (formed of 2-7 impulses and lasting for 5-11 ms) (Fig. $3 \mathrm{~g}, \mathrm{~h})$.

Pholidoptera frivaldskyi (Herman). Material: 1 + , „Codrii” Natural Reserve, 25.07.2012, leg. N. Stahi. Mesophytic species, praticolous. Adults are found during VI-IX. This is the first record of the species in the Republic of Moldova.

Onconotus servillei Fischer von Waldheim. Material: $3 \hat{\delta} \widehat{\partial}$, Valea lui David (Iaşi), 23.07.2013, leg. I. Ş. Iorgu. It is a xerophytic species, praticolous and geobiont, very rare in the studied area. Adults are found during VI-VIII. Bioacoustics: the song consists of a long series of trisyllabic groups. Syllable length varies between $18-31 \mathrm{~ms}$, the last one with highest sound amplitude (Figs $3 \mathrm{i}, \mathrm{j} ; 4 \mathrm{~b}$ ).

Gryllomorpha dalmatina (Ocskay). Material: 1 , , Slobozia-Mare, 12.08.2007, leg. N. Stahi. Adults are found during VIII-XI. Although the species Gryllomorpha dalmatina (Ocskay) was encountered only on the eastern shores of Prut River, it is likely that this species exists also in Romania.

Paracaloptenus caloptenoides (Brunner von Wattenwyl). Material: $1 \delta^{\lambda}$ and 1ㅇ, Bârnova forest, 26.08.2008, leg. I. Ş. Iorgu. It is a geobiont and thermophilous species, living in forest clearings. Adults are found during VII-IX. The species is listed in Habitat Annex II (Natura 2000 code: 4053).

Locusta migratoria (Linnaeus). Since ancient times, this species is considered a pest and thus became the most well-known grasshopper. In Eastern Europe, it formed large swarms that destroyed cultures and hayfields alike, up to the 1950's, when the use of chemical insecticides became more and more common. Since that time, the actual effectives of Locusta and other insects diminished drastically; already in early 70's the last refuges of Locusta migratoria in Eastern Europe remained the lower Prut River and the Danube Delta (Kis \& Vasiliu, 1970). Recently, in the period 16-23 July 2009, a massive swarm took place in Taraclia and Ceadâr-Lunga districts (Republic of Moldova), destroying 54 ha of corn crops. Massive doses of chemical insecticides were used to annihilate the insects (Stahi \& Gaibu, 2010). In the same period, several individuals showing conspicuous "migratory phase" characteristics 
have been found in the counties Tulcea, Galaţi, Vaslui and Iaşi (Romania), most likely belonging to the same swarm (I. Ş. Iorgu, unpublished). Adults can be found during VII-IX.

Psophus stridulus (Linnaeus) and Omocestus viridulus (Linnaeus). Adults are found during VII-IX. Both are characteristic mountain species and rarely occur in lowland areas, such as Prut Basin. Material: Psophus stridulus (Linnaeus): 1 o, „Codrii” Natural Reserve, 02.08.2006, leg. N. Stahi; Omocestus viridulus

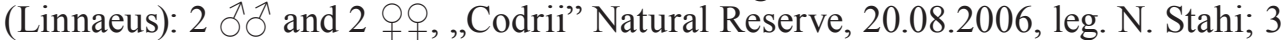
$\widehat{\partial} \hat{\delta}$ and 2 우, Moara Domnească, 21.08.2006, leg. N. Stahi.

Dociostaurus maroccanus (Thunberg). This is a xerophytic, geobiont species and adults are found during VII-X. Extremely rare in the studies area: $1 \hat{\delta}$ and 1

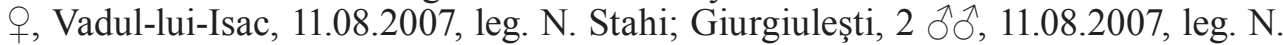
Stahi.

Chorthippus macrocerus purpuratus (Voroncovskij). It is a meso- and xerophytic, praticolous species. The distribution area of the species has its western most limit in E Romania. Adults can be found during VII-X (Fig. 4 f).

Chorthippus oschei pusztaensis Vedenina \& Helversen, O. von. This subspecies occurs in Hungary, Croatia, Serbia, Macedonia, Bulgaria, Ukraine, Romania, Republic of Moldova (Vedenina \& Helversen, O. von, 2009), Slovakia (Krištín et al., 2011). Adults can be found during VII-X. Along the Prut Basin, there is a hybridization area with Chorthippus albomarginatus (De Geer) (Vedenina \& Helversen, O. von, 2003; Vedenina et al., 2007). Many collected specimens showed intermediary morphological characters and mating rituals between the two species.

Other species mentioned in the literature (Mîndru, 1980; Mîndru \& Kis, 1967) from Valea lui David from the 1960's to the 1980's are Bradyporus dasypus (Illiger) and Callimenus macrogaster longicollis (Fieber). The species have never been found since the last recording and they are possibly extinct from Prut River Basin.

\section{ACKNOWLEDGEMENTS}

Nadejda Stahi's work was supported by Institutional Applied Project 11.817.08.16A, financed by ASM. We are thankful to the anonymous reviewers for their comments on the manuscript.

\section{ORTOPTERELE (INSECTA) DIN BAZINUL PRUTULUI MIJLOCIU ȘI INFERIOR}

\section{REZUMAT}

$\mathrm{Au}$ fost studiate preferinţele ecologice şi bioacustica speciilor de cosaşi, greieri şi lăcuste din bazinul mijlociu și inferior al Prutului, cercetări efectuate în 55 localităţi din România şi în 33 localităţi din Republica Moldova. Un număr total de 91 specii de ortoptere au fost colectate în zona de studiu: 85 specii au fost întâlnite în partea vestică a râului Prut (9 Phaneropteridae, 24 Tettigoniidae, 1 Bradyporidae, 5 Gryllidae, 1 Gryllotalpidae, 1 Tridactylidae, 5 Tetrigidae, 39 Acrididae) şi 76 specii au fost găsite pe partea estică (7 Phaneropteridae, 19 Tettigoniidae, 1 Bradyporidae, 5 Gryllidae, 1 Gryllotalpidae, 1 Tridactylidae, 3 Tetrigidae, 39 Acrididae). Patru specii sunt semnalate pentru prima data în Republica Moldova: Barbitistes constrictus (Fabricius), Poecilimon fussii Brunner von Wattenwyl, Metrioptera roeselii fedtschenkoi (Saussure) şi Pholidoptera frivaldskyi (Herman).

\section{LITERATURE CITED}

BIZUȚCHI, I., 2004 - Diversitatea faunei în rezervaţia naturală „Pădurea Domnească”. Buletinul Ştiinţific. Revistă de Etnografie, Ştiinţe ale Naturii şi Muzeologie, 1 (14): 193-195. (in Romanian)

CHOBANOV, D. P., 2009 - New records and a new synonym of Orthoptera from Bulgaria. Articulata, $24(1 / 2): 79-108$. 
DERJANSCHI, V., G. BUŞMACHIU, L. CALESTRU, E. BABAN, M. GÂRNET, N. STAHI, 2006 Forestry entomocoenoses from the Reserve "Plaiul Fagului". Scientific Bulletin. Journal of Ethnography, Natural Sciences and Museology, 4 (17): 57-60.

HELLER, K.-G., K. M. ORCI, G. GREIN, S. INGRISCH, 2004 - The Isophya species of Central and Western Europe (Orthoptera: Tettigonioidea: Phaneropteridae). Tijdschrift voor Entomologie, 147: 237-258.

HAMMER, Ø., D. A. T. HARPER, P. D. RYAN, 2001 - PAST: Paleontological statistics software package for education and data analysis. Palaeontologia Electronica 4 (1), 9 p. (http://palaeoelectronica.org/2001_1/past/issue1_01.htm)

IORGU, I. Ş., K.-G. HELLER, 2013 - The bush-cricket Isophya kraussii (Orthoptera: Phaneropteridae): bioacoustics, distribution and description of a new subspecies from Romania. Zootaxa, 3640 (2): 258-269.

IORGU, I. Ş., E. I. IORGU, 2008 - Bush-crickets, crickets and grasshoppers from Moldavia (Romania). Edit. Pim Iaşi, Romania, 294 p.

IORGU, I. Ş., E. I. PISICÂ, 2006 - Contributions to the distribution knowledge of some Orthoptera species (Insecta: Orthoptera) from Eastern Romania. Complexul Muzeal de Ştiinţele Naturii "Ion Borcea" Bacău - Studii şi Comunicări, 21: 251-256.

IORGU, I. Ş., E. I. PISICĂ, 2008 - The Orthoptera (Insecta: Orthoptera) from Moldavia (Romania): checklist and some ecological aspects. Lucrările Simpozionului Entomofagii şi rolul lor în păstrarea echilibrului natural. Analele Ştiinţifice ale Universităţii "Al. I. Cuza" din Iaşi (Serie nouă), supliment al seriei Biologie Animală: 201-212.

IORGU, I., E. PISICÂ, L. PĂIŞ, G. LUPU, C. IUŞAN, 2008 - Checklist of Romanian Orthoptera (Insecta) and their distribution by eco-regions. Travaux du Muséum National d'Histoire Naturelle "Grigore Antipa", 51: 119-135.

KIS, B., M. VASILIU, 1970 - Kritisches Verzeichnis der Orthopterenarten Rumäniens. Travaux du Muséum d'Histoire Naturelle "Grigore Antipa", 10: 207-227.

KOLICS, B., Z. ÁCS, D. P. CHOBANOV, K. M. ORCI, L. S. QIANG, B. KOVÁCS, E. KONDOROSY, K. DECSI, J. TALLER, A. SPECZIÁR, L. ORBÁN, T. MÜLLER, 2012 - Re-visiting phylogenetic and taxonomic relationships in the genus Saga (Insecta: Orthoptera). PLoS ONE, 7 (8): 1-13 (e42229).

KRIŠTÍN, A., M. BALLA, V. FABRICIUSOVÁ, V. HRÚZ, P. KAŇUCH, 2011 - Orthoptera and Mantodea in fragments of seminatural habitats in lowlands of SE Slovakia and SW Transcarpathian Ukraine. Articulata, 26 (2): 109-121.

MÎNDRU, C., 1958 a - Contribuţii la Studiul Ortopterelor din Moldova (Nota a III-a). Studii şi Cercetări Ştiinţifice - Biologie şi Ştiinte Agricole, Iaşi, 9 (2): 291-297. (in Romanian)

MÎNDRU, C., 1958 b - Contribuţii la Studiul Acridienilor din Moldova. Analele Ştiinţifice ale Universităţii „Al. I. Cuza“ Iaşi (serie nouă), secţiunea II (Ştiinţe Naturale), 3 (1): 103-107. (in Romanian)

MÎNDRU, C., 1960 - Contribuții la Studiul Ortopterelor din Moldova. Subordinul Ensifera. Analele Ştiinţ̧ifice ale Universităţii „Al. I. Cuza“ Iaşi (serie nouă), secţiunea II (Ştiinţe Naturale), 6 (1): 129-133. (in Romanian)

MÎNDRU, C., 1980 - Fauna de orthoptere din Fîneţele Seculare de la Valea lui David. Analele Ştiinţifice ale Universităţii „Al. I. Cuza“ Iaşi (serie nouă), secţiunea II (Ştiinţe Naturale), a. Biologie, 26: 93-95. (in Romanian)

MÎNDRU, C., B. KIS, 1967 - Contribuţii la studiul suprafamiliei Tettigonioidea (Orthoptera) din Regiunea Iaşi. Analele Ştiinţifice ale Universităţii „Al. I. Cuza“ din Iaşi (serie nouă), secţiunea II (Ştiinţe Naturale), a. Biologie, 13 (1): 83-89. (in Romanian)

OPREA, A., G. DAVIDEANU, A. DAVIDEANU, I. E. POPESCU, I. ION, C. GACHE, 2008 a Lista roşie a speciilor de floră şi faună sălbatică din zona de graniţă România - Republica Moldova. Agenția pentru Protecția Mediului Iaşi, România, 72 pp. (in Romanian)

OPREA, A., G. DAVIDEANU, A. DAVIDEANU, I. E. POPESCU, I. ION, C. GACHE, 2008 b Starea de conservare a biodiversităţii în zona transfrontalieră România - Republica Moldova. Agenţia pentru Protecţia Mediului Iaşi, România, 70 pp. (in Romanian)

POPESCU, I. E., 2013 - Rezervaţia de fâneţe seculare de la Valea lui David Iaşi. Pp. 169-186. In: Ș. Susai (ed.), Comuna Miroslava. Despre locuri şi oameni. Edit. Masterprint, Iaşi, Romania, 208 p. (in Romanian)

PRICOP, E., B.-M. NEGREA, I. E. POPESCU, I. Ş. IORGU, 2012 - First record of Saga pedo (Orthoptera, Tettigoniidae) in Suceava county with notes on its distribution in Eastern Romania. Advances in Environmental Sciences - International Journal of the Bioflux Society, 4 (3): 171-177. 
RADU, G., I. TICALO, D. BURUIANA, 2012 - The Prut floodplain potential Ramsar site. Current situation and perspectives. Pp. 471-485. In: P. Gâştescu, W. Lewis Jr., P. Brețcan (eds), Water resources and wetlands. Conference Proceedings, Tulcea, România.

RAGGE, D. R., W. J. REYNOLDS, 1998 - The songs of the grasshoppers and crickets of Western Europe. Harley Books, Colchester, Essex CO6 4AH, England, 591 pp.

STAHI, N., 2006 - Step insects of grasshoppers (Insecta, Orthoptera) from the south of the Republic of Moldova. Muzeul Olteniei Craiova. Oltenia. Studii şi comunicări. Ştiinţele Naturii, 22: 126-127.

STAHI, N., 2007 a - Faunistic and synecological research of grasshoppers (Insecta, Orthoptera) from scientific reservations from the Republic of Moldova. Muzeul Olteniei Craiova. Oltenia. Studii şi comunicări. Ştiinţele Naturii, 23: 111-114.

STAHI, N., $2007 \mathrm{~b}$ - Contribution to the knowledge of diversity and ecology of crickets (Insecta: Orthoptera, Grylloidea) from the Republic of Moldova. Scientific Bulletin. Journal of Ethnography, Natural Sciences and Museology, 6 (19): 80-85.

STAHI, N., 2009 - Grasshoppers (Insecta: Orthoptera) from the Scientific Reserve "Pădurea Domnească". International Symposium dedicated to the 70th birthday anniversary of Professor Andrei Munteanu „Diversity, valorisation and protection of the animal world”: 228-232.

STAHI, N., V. DERJANSCHI, 2007 - Fauna of Orthoptera order from landscape reserve "One hundred Knolls" (Republic of Moldova). Materials of the sixth International Scientific Conference „Youth in solving regional and Trans-national problems of ecological safety”: 223-226.

STAHI N., V. DERJANSCHI, 2008 - Materials above ecology and distribution of insects of Orthoptera order from landscape reserve "One hundred Knolls" (Republic of Moldova). Muzeul Olteniei Craiova. Oltenia. Studii şi comunicări. Ştiinţele Naturii, 24: 61-64.

STAHI N., V. DERJANSCHI, 2010 - Faunistic data on Orthoptera insects from the Scientific Reserve "Lower Prut" from the Republic of Moldova. International symposium „Ecology and protection of ecosystems", 23: 38-43.

STAHI N., V. DERJANSCHI, 2011 a - Faunistic data on Orthoptera insects from the Scientific Reserve "Plaiul Fagului" (Republic of Moldova). Muzeul Olteniei Craiova. Oltenia. Studii şi comunicări. Ştiinţele Naturii, 27 (1): 81-86.

STAHI N., V. DERJANSCHI, 2011 b - Rare species of Orthoptera (Insecta) from the Republic of Moldova. Muzeul Olteniei Craiova. Oltenia. Studii şi comunicări. Ştiinţele Naturii, 27 (2): 47-50.

STAHI N., V. DERJANSCHI, 2012 - The spatial structure of orthopteran communities from the Scientific Reserve "Codrii" from the Republic of Moldova. Muzeul Olteniei Craiova. Oltenia. Studii şi comunicări. Ştiinţele Naturii, 28 (2): 57-62.

STAHI, N., Z. GAIBU, 2010 - Lăcustele (Insecta, Orthoptera) invazive în Republica Moldova. AGRO - buletin AGIR, 2 (5): 45-52. (in Romanian)

VEDENINA, V. YU., O. von HELVERSEN, 2003 - Complex courtship in a bimodal grasshopper hybrid zone. Behavioral Ecology and Sociobiology, 54: 44-54.

VEDENINA, V. YU., O. von HELVERSEN, 2009 - A re-examination of the taxonomy of the Chorthippus albomarginatus group in Europe on the basis of song and morphology (Orthoptera: Acrididae). Tijdschrift voor Entomologie, 152: 65-97.

VEDENINA, V. YU., A. K. PANYUTIN, O. von HELVERSEN, 2007 - The unusual inheritance pattern of the courtship songs in closely related grasshopper species of the Chorthippus albomarginatus - group (Orthoptera: Gomphocerinae). Journal of Evolutionary Biology, 20: 260-277.

ZAMFIRESCU, Ş. R., O. ZAMFIRESCU, C. ION, I. E. POPESCU, 2007 - Research on the habitats of Vipera ursinii moldavica populations from Iaşi county. Analele Ştiinţifice ale Universităţii „Al. I. Cuza” Iaşi, s. Biologie animală, 53: 159-166.

ZAMFIRESCU, Ş. R., O. ZAMFIRESCU, I. E. POPESCU, C. ION, 2009 - Preliminary data on the population characteristics of Vipera ursinii moldavica from "Dealul lui Dumnezeu" (Iaşi County, Romania) with notes on conservation. North-Western Journal of Zoology, 5 (1): $85-96$.

***IUCN 2013 - IUCN Red List of Threatened Species. Version 2013.2. <www.iucnredlist.org>. Downloaded on 20 November 2013. 
Received: November 15, 2013 Accepted: December 24, 2013
Ionuţ Ştefan Iorgu, Elena Iulia Iorgu

"Grigore Antipa" National Museum of Natural History Şos. Kiseleff 1, 011341 Bucharest 2, Romania

e-mails: nusi81@yahoo.com elenap@antipa.ro

Nadejda Stahi

Institute of Zoology of Academy of Science of Moldova Academiei street, no. 1, 2028 Chișinău,

Republic of Moldova

e-mail: n_stahi@yahoo.com 